\title{
EFFECT OF LEVEL OF MILK PRODUCTION ON PROFITABILITY IN LACTATING EGYPTIAN BUFFALOES
}

\author{
El-Awady, H. G. ${ }^{1}$; Salem, A. Y. ${ }^{1}$ and Shoaib, A. ${ }^{1}$ \\ Department of Animal Production, Faculty of Agriculture, Kafrelsheikh \\ University, Egypt (hassanelawady63@yahoo.com)
}

\begin{abstract}
A total of 1012 lactation records of 426 Egyptian buffalo cows mated by 118 sires maintained at Mahallet Mousa Experimental farms of Animal Production Research Institute (APRI), were analyzed to estimate the economic value of some productive and reproductive traits under different levels of milk production from year 2000 to 2012 . Traits studied were total milk yield (TMY, $\mathrm{kg}$ ), lactation period (LP, day), dry period (DP, day), days open (DO, day) and calving interval $(\mathrm{Cl}$, day). Data divided into three levels of milk production: $\mathrm{L} 1$ (low level), L2 (medium level) and L3 (high level). The average of TMY, LP, DP, $\mathrm{DO}$ and $\mathrm{Cl}$ in the three levels of milk production were $990 \mathrm{~kg}, 191.75 \mathrm{~d}, 262.87$ $\mathrm{d}, 136.64 \mathrm{~d}$ and $454.63 \mathrm{~d}$, respectively in the $\mathrm{L} 1,1662 \mathrm{~kg}, 202.05 \mathrm{~d}, 253.48 \mathrm{~d}$, $138.57 \mathrm{~d}$ and $455.77 \mathrm{~d}$, respectively in the L2 and $2228 \mathrm{~kg}, 206.06 \mathrm{~d}, 246.53 \mathrm{~d}$, $135.56 \mathrm{~d}$ and $452.59 \mathrm{~d}$, respectively in the L3. Least squares analysis of variance showed a significant $(\mathrm{P}<0.05$ and $\mathrm{P}<0.01)$ effect of all factors on all traits studied except the effect of level of milk production on dry period, days open and calving interval was non-significant. Economic evaluations indicated that the annual variable cost were (EGP) (Egyptian pound $=0.11 \mathrm{USD}$ and $=$ 0.09 EUR) 6980,8860 and 10038 of L1, L2 and L3, respectively. However, the annual gross margin of $L 3$ was higher than that of $L 2$ and $L 1$ by $79.55 \%$ and $276.94 \%$, respectively, and the benefit /cost ratio was $1.11,1.19$ and 1.29 for L1, L2 and L3, respectively. The profit per buffalo cow during the lifetime production of L3 was $88.56 \%$ (5342 EGP) and $349.92 \%$ (8846 EGP) more than of $L 2$ and $L 1$, respectively. The present results indicated that high milk producers buffaloes (L3) with longer lactation period but shorter dry period, days open and calving interval are more profitable than those have shorter lactation period and longer dry period, days open and calving interval.
\end{abstract}

Key words: benefit/cost ratio, gross margin, milk levels, economic traits, buffalo.

\section{INTRODUCTION}

Buffalo is considered the main dairy animal in Egypt. The total numbers of buffaloes nearly about 3.95 million buffaloes (MARL, 2015). The domestic buffalo is an important animal in the agricultural economy of many countries like Egypt. Most of buffaloes are owned by small holders and it depended nearly 65 to 70 of total milk in the country. 
Productive and reproductive traits are affected by non-genetic factors. Evaluation of non-genetic effects provides basic information for developing breeding and management programs for genetic improvement. It helps in selecting sires and dams with superior genetic merits (Hintz et al., 1978). Milk yield is the most important trait of a dairy animal. Higher milk yield increases the profitability and decreases the rearing cost of dairy animals (Zafar et al., 2008).

High milk production plays an important role in this aspect. And great economic importance under Egyptian environments where there is a large variability in terms of feed quality and quantity feed effect in developing productive and reproductive traits. Buffaloes, because of their higher milk fat content than cattle, are extensively reared in Pakistan on small scale for family consumption of milk, with the surplus milk being sold to compensate the family budget.

Total losses due to under-managed health, nutrition and reproduction coupled with the hostile marketing system causes an annual loss of US\$10 billion to the Pakistan's economy (Qureshi et al., 2002). The aim of the present study was to estimate the profitability of buffalo cow kept at Mahallet Mousa farms with different levels of milk production.

\section{Data and management}

\section{MATERIALS AND METHODS}

Data of 1012 lactation records of 426 Egyptian buffalo cows mated by 118 sires raised at Mahallet Mousa Experimental farms (El-Gaded, Main Mahallet Mousa (Main M. Mousa) and El-Kadem) of Animal Production Research Institute (APRI), Ministry of Agriculture, Egypt, were used in the present study. Records covered the period from 2000 to 2012. Buffalo cows were mated naturally. Pregnancy was detected by rectal palpation 60 days after the last service. Data divided into three levels: L1 (low level $=122$ records), milk production per day was up to 6 $\mathrm{kg}$ or less, L2 (medium level $=709$ records), milk production per day was more than 6 to $10 \mathrm{~kg}$ and L3 (high level $=181$ records), milk production per day was more than $10 \mathrm{~kg}$. Traits investigated in the present study were some productive traits such as: total milk yield (TMY, $\mathrm{kg}$ ), lactation period (LP, day), and dry period (DP, day) and some reproductive traits such as: days open (DO, day) and calving interval (Cl, day).

Animals were kept under semi-open sheds. Lactating buffaloes were milked by hand or machine twice daily at 7.00 a.m and 4.00 p.m throughout the lactation period, and milk production was recorded daily. Buffaloes were kept under the routine feeding with according to level of production and managerial system in Mahallet Mousa Experimental farms. The Animals were grazed on Egyptian clover 
(Trifolium Alexandrinum) during December to May with concentrate mixture and rice straw. While during June to November, animals were fed on concentrate mixture, rice straw and limited amount of clover hay or (silage). Animals were feed according to their live weight, milk production and reproductive status. The concentrate feed mixture was given twice daily before milking, while rice straw was offered once daily at $9.00 \mathrm{a} . \mathrm{m}$, whereas clover hay or (silage) in Summer was offered at 11.00 a.m, animals were allowed to drink water three times a day or free from water troughs. Multi mineral licking blocks were available for animals in the stalls.

\section{Statistical analysis}

Data were analyzed using fixed model least squares and maximum likelihood computer program of Harvey (1990), to determine the main effects. The statistical model included month (1 to 12) and year (2000 to 2012) of calving, parity (1 to 9 ) and levels of milk production (1 to 3). The following full fixed model was used:

Where:

$$
Y_{i j k l m}=\mu+M_{i}+Y_{j}+P_{k}+L_{i}+\beta(A F C)+e_{i j k l m}
$$

$\mathrm{Y}_{\mathrm{ijklm}}=$ observation of the productive and reproductive traits;

$\mu \quad=$ the overall mean;

$\mathrm{M}_{\mathrm{i}} \quad$ = fixed effect of $\mathrm{i}^{\text {th }}$ month of calving;

$Y_{j} \quad=$ fixed effect of $j^{\text {th }}$ year of calving;

$P_{k} \quad=$ fixed effect of $k^{\text {th }}$ parity;

$L_{1} \quad=$ fixed effect of $I^{\text {th }}$ level of milk production;

$\beta(A F C)=$ linear and quadratic regression coefficients of the traits studied on age at first calving and

$\mathrm{e}_{\mathrm{ijklm}} \quad=$ random error term.

\section{Technical confidents and assumptions}

Data were statistically analyzed to estimate the productive and reproductive technical coefficients of the three levels of milk production.

Table (1): Assumptions adopted in calculating farm budget

\begin{tabular}{|l|c|c|c|}
\hline \multirow{2}{*}{ Items } & \multicolumn{3}{c|}{ Levels } \\
\cline { 2 - 4 } & LMY(L1) & MMY(L2) & HMY(L3) \\
\hline Number of records (1012) & 122 & 709 & 181 \\
\hline Average mature body weight (kg) & 550 & 600 & 650 \\
\hline Average of age at first calving (mo.) & 37.41 & 36.50 & 37.29 \\
\hline No of service per conception & 2.5 & 2.5 & 3 \\
\hline Average calf sale price at birth (EGP) & 3500 & 3500 & 3500 \\
\hline Average cost of an insemination (EGP) & 40 & 40 & 40 \\
\hline Average annual veterinary care cost (EGP) & 150 & 150 & 200 \\
\hline Average annual manure production per head (m ${ }^{3}$ ) & 14 & 15 & 17 \\
\hline Average price of m ${ }^{3}$ manure (EGP) & 70 & 70 & 70 \\
\hline Average rectal palpation / time (EGP) & 50 & 50 & 50 \\
\hline Average sale price of 1 kg milk in farm (EGP) & 5 & 5 & 5 \\
\hline
\end{tabular}

* The prices of inputs are based on the current market price.

* The prices of outputs are based on the current farm price. 
* Gross margin is one of the more realistic measures to evaluate farm profitability (Barnard and Mix, 1993). To compare among three levels, the annual gross margins as well as, discounted measure, benefit/cost ratio (present worth of benefits divided by present worth of costs) were used as economic tools for comparing the three levels studied (El-Awady, 2013).

\section{Statistical descriptive}

\section{RESULTS AND DISCUSSION}

The overall means, standard deviation (SD) for different traits studied are presented in Table (2). Means of TMY, LP, DP, DO and Cl were $1682 \mathrm{~kg}, 202$ day, 253 day, 138 day and 455 day, respectively.

Table (2): Means and standard deviations for productive, reproductive and lifetime production traits for the three levels investigated

\begin{tabular}{|c|c|c|c|c|}
\hline \multirow[b]{2}{*}{ Trait } & \multirow[b]{2}{*}{ All lactation } & \multicolumn{3}{|c|}{ Levels } \\
\hline & & L1 (LMY) & L2 (MMY) & L3 (HMY) \\
\hline \multicolumn{5}{|l|}{ Productive traits } \\
\hline Daily milk yield (M/D, $\mathrm{kg}$ ) & $8.31 \pm 0.19$ & $4.99 \pm 0.86$ & $8.17 \pm 1.04$ & $11.07 \pm 0.69$ \\
\hline Total milk yield (TMY, kg) & $1682 \pm 562$ & $990 \pm 386.00$ & $1662 \pm 834.55$ & $2228 \pm 541.75$ \\
\hline Lactation period (LP, day) & $202 \pm 43$ & $191.75 \pm 41.27$ & $202.05 \pm 42.33$ & $206.06 \pm 46.71$ \\
\hline Dry period (DP, day) & $253 \pm 109$ & $262.87 \pm 90.28$ & $253.48 \pm 108.07$ & $246.53 \pm 126.43$ \\
\hline Annual milk yield (AMY, kg) & 1349 & 795 & 1331 & 1797 \\
\hline \multicolumn{5}{|l|}{ Reproductive traits } \\
\hline Days open (DO, day) & $138 \pm 98$ & $136.64 \pm 79.12$ & $138.57 \pm 98.46$ & $135.56 \pm 109.90$ \\
\hline Calving interval (Cl, day) & $455 \pm 98$ & $454.63 \pm 78.99$ & $455.77 \pm 98.42$ & $452.59 \pm 109.89$ \\
\hline Age at first calving (AFC) & $36.75 \pm 6.54$ & $37.41 \pm 6.76$ & $36.50 \pm 6.50$ & $37.29 \pm 6.54$ \\
\hline \multicolumn{5}{|l|}{ Lifetime production traits } \\
\hline $\begin{array}{l}\text { No. of lactations complete } \\
\text { (NLC) }\end{array}$ & $2.87 \pm 0.64$ & $3.10 \pm 0.64$ & $2.93 \pm 0.63$ & $2.59 \pm 0.64$ \\
\hline Lifetime milk yield (LTMY, kg) & 10304 & 6792 & 10590 & 13062 \\
\hline Number of records & 1012 & 122 & 709 & 181 \\
\hline
\end{tabular}

The present results of total milk yield was higher than obtained by Mourad et al., (2005) and El-Azab, (2006) in Egyptian buffaloes, they found that the mean of total milk yield was 1581 and $1245 \mathrm{~kg}$, respectively. Mourad and Khattab, (2009) reported that the lactation period was 184 days in Egyptian buffaloes. Hussain et al., (2006); Mentiel et al., (2013) and Sanker et al., (2014) estimated the average mean of dry period was $143.88,144.34$ and 205.34 days, respectively. Barros et al., (2013) and Mentiel et al., (2013) found that calving interval was 423 and 430 days in different breeds of buffaloes. While was lower than those obtained by, Khan et al., (2008) showed that average for three levels, L1 was (2630 kg and 291 day), L2 was (2682 $\mathrm{kg}$ and 289 day) and L3 was (2836 kg and 291 day) for total milk yield and lactation period, respectively. In Egyptian buffaloes, Abu El-Naser, (2008) reported that the average mean of milk yield was $2054 \mathrm{~kg}$, while El-Awady, (2009) on the other sets of this data found that total milk yield (TMY) was $2055 \mathrm{~kg}$. Also, Abo Gamoes, (2012) was $2070 \mathrm{~kg}$. Another authors (Aziz et al., 2001; Mahdy et al., 2001; EL-Azab, 2006 and Khattab and Mourad, 2007) in Egyptian buffaloes, found that longer 
lactation period than in the present study were 208.6, 254.6, 296 and 282 days respectively. Ahmad et al., (2013) and Barros et al., (2014) found the lactation period was 246.3 and 269.57 day in Nili-Ravi and Brazilian buffaloes, respectively.

In Egyptian buffaloes, Aziz et al., (2001) found that longer dry period than in the present study (307.3 day) and days open (199 day). In addition the present mean of dry period is nearly that estimated by Khan et al., (2007) in Pakistan (250 day) and Thiruvenkadan et al., (2010) in India (250.5 day). Mahdy et al., (2001) in Egyptian buffaloes, found that longer calving interval than in the present study (528 day). Khan et al., (2007) calculated the calving interval (540 day) in Pakistani buffaloes. In addition the present mean of calving interval is nearly to that estimated by Sanker et al., (2014) in Murrah buffaloes (450 day).

Least squares analysis of variance showed significant $(P<0.05$ and/or $\mathrm{P}<0.01$ ) effect of all factors on all traits studied except the effect of level of production on dry period, days open and calving interval was non-significant (Table 3). These results agree with those in Egyptian buffaloes, reported by El-Azab, (2006) and Abo Gamoes, (2012) reported that the month or season and year of calving had highly significant $(\mathrm{P}<0.01)$ effect on milk yield. In addition, Mourad et al., (1990); Khalil et al., (1992) and Awad and Hassan, (2006), they also reported that month or season and year of calving had highly significant $(P<0.01)$ effect on lactation period.

Table (3): Least square analysis of variance for total milk yield (TMY), lactation period (LP), dry period (DP), days open (DO) and calving interval (Cl) in Egyptian buffaloes

\begin{tabular}{|c|c|c|c|c|c|c|}
\hline \multirow[b]{2}{*}{ S.O.V } & \multirow[b]{2}{*}{ d.f } & \multicolumn{5}{|c|}{ F-Significance * } \\
\hline & & TMY & LP & DP & DO & $\mathrm{Cl}$ \\
\hline Month of calving & 11 & $3.64^{\star \star}$ & $4.18^{\star \star}$ & $3.30^{\star \star}$ & $2.39^{\star *}$ & $2.40^{\star *}$ \\
\hline Year of calving & 12 & $5.69^{\star *}$ & $6.27^{\star *}$ & $9.82^{* *}$ & $8.26^{* *}$ & $8.37^{\star \star}$ \\
\hline Parity & 8 & $6.31^{* *}$ & $2.76^{\star \star}$ & $22.62^{* *}$ & $28.00^{* *}$ & $27.54^{\star *}$ \\
\hline $\begin{array}{l}\text { Level of milk } \\
\text { production }\end{array}$ & 2 & $96.79^{* *}$ & $3.40^{*}$ & $0.43^{\mathrm{ns}}$ & $0.02^{\mathrm{ns}}$ & $0.01^{\mathrm{ns}}$ \\
\hline Residual, M.S. & 881 & 1565.36 & 1507.17 & 8744.17 & 6888.59 & 6885.77 \\
\hline
\end{tabular}

* Significant at $\mathrm{P}<0.05$, ${ }^{* *}$ significant at $\mathrm{P}<0.01$, ns $=$ not significant.

Aziz et al., (2001) and Awad and Hassan, (2006) in Egyptian buffaloes, reported that the season of calving had highly significant effect $(P<0.01)$ on days open, dry period and calving interval. In addition, Abu El-Naser, (2008); El-Awady, (2009) and Abo Gamoes, (2012) reported that the parity had significant effect $(P<0.01)$ on the total milk yield. 


\section{Economical assessment}

Income (gross output) of L3 was more than that L2 and L1 as about $23.68 \%$ and $67.38 \%$ respectively, while L2 was more than L1 by about $35.32 \%$. This may be attributed to the higher milk revenues. Milk yield is considered the major source of farm revenues. The current study showed $51.19 \%, 63.33 \%$ and $69.12 \%$ of the total gross output for L1, L2 and L3, respectively (Table 4).

Annual variable cost per buffalo cow of L3 was higher than those of L2 and L1 by about $13.29 \%$ and $43.81 \%$ respectively, while L2 was higher than L1 by about $26.93 \%$. This difference among the three levels can attributed mainly to the extra feeds to cover extra milk production, the labor and insemination cost for breeding.

Table (4): Analysis of the annual gross output (income) (EGP) and variable costs (EGP) per buffalo cow of the three levels

\begin{tabular}{|l|c|c|c|}
\hline \multirow{2}{*}{ Item } & \multicolumn{3}{c|}{ Levels } \\
\cline { 2 - 4 } & LMY (L1) & MMY (L2) & HMY (L3) \\
\hline Gross output (income) & 3975 & 6655 & 8984 \\
\hline Milk & 2810 & 2803 & 2823 \\
Calves & 980 & 1050 & 1190 \\
Manure & 7765 & 10508 & 12997 \\
Total gross output & \multicolumn{3}{c}{} \\
\hline Variable cost (outcome) & 6055 & 7935 & 8968 \\
\hline Feeding & 550 & 550 & 600 \\
Labor & 100 & 100 & 100 \\
Insemination & 125 & 125 & 125 \\
Palpation & 150 & 150 & 200 \\
Veterinary care & 6980 & 8860 & 10038 \\
Total variable cost & 785 & 1648 & 2959 \\
\hline Gross margin & 1.11 & 1.19 & 1.29 \\
Benefit / cost ratio & 1.00 & 2.1 (L2 vs L1) & 1.8 (L3 vs L2) \\
Annual gross margin (consider L1 as the unit) & & & 3.8 (L3 vs L1) \\
\hline
\end{tabular}

Feeding represented the major element of the variable cost. It represented $86.74 \%, 89.56 \%$ and $89.34 \%$ for L1, L2 and L3, respectively on out of the total variable costs for levels of milk production (Table 4). Annual gross margin of L3 increased by $79.55 \%$ high rate from L2 and 276.94 from L1, it contributing 785, 1648 and 2959 for L1, L2 and L3, respectively. Also benefit/cost ratio increased in L3 by 8.40 and $16.2 \%$ than $L 2$ and $L 1$, respectively.

Results of the financial analysis per buffalo cow during its lifetime production are presented in Table (5). As economical evaluation, the overall variable cost for the whole lifetime production of L3 exceeded that of L2 by $18.99 \%$ (6159 EGP) and exceeded that of L1 by $71.68 \%$ (16111 EGP), and L2 was higher than L1 by about $44.28 \%$ (9952 EGP). While, the total gross output of L3 exceeded those of L2 and L1 by 29.90 
\% (11501 EGP) and $99.81 \%$ (24957 EGP) respectively, while L2 was higher than L1 by about $53.81 \%$ (13456 EGP).

The profit per cow during the lifetime of L3 was more than L2 and L1 by about $88.56 \%$ (5342 EGP) and 349.92 (8846 EGP), respectively, and L2 was higher than L1 by about 138.60 (3504 EGP).

Table (5): Financial analysis (EGP) for lifetime production per cow of the three levels and percentages of difference among levels investigations

\begin{tabular}{|c|c|c|c|c|c|c|}
\hline \multirow{2}{*}{ Item } & \multicolumn{3}{|c|}{ Levels } & \multicolumn{3}{c|}{$\%$ difference between levels } \\
\cline { 2 - 7 } & LMY (L1) & MMY (L2) & HMY (L3) & L3 vs L2 & L3 vs L1 & L2 vs L1 \\
\hline $\begin{array}{c}\text { Gross } \\
\text { output }\end{array}$ & 25003 & 38459 & 49960 & $\begin{array}{c}+29.90 \\
(11501 \text { EGP }\end{array}$ & $\begin{array}{c}+99.81 \\
(24957 \text { EGP }\end{array}$ & $\begin{array}{c}+53.81 \\
(13456 \text { EGP }\end{array}$ \\
\hline $\begin{array}{c}\text { Variable } \\
\text { cost }\end{array}$ & 22475 & 32427 & 38586 & $\begin{array}{c}+18.99 \\
(6159 \text { EGP }\end{array}$ & $\begin{array}{c}+71.68 \\
(16111 \mathrm{EGP}\end{array}$ & $\begin{array}{c}+44.28 \\
(9952 \mathrm{EGP})\end{array}$ \\
\hline $\begin{array}{c}\text { Gross } \\
\text { margin }\end{array}$ & 2528 & 6032 & 11374 & $\begin{array}{c}+88.56 \\
(5342 \mathrm{EGP})\end{array}$ & $\begin{array}{c}+349.92 \\
(8846 \mathrm{EGP})\end{array}$ & $\begin{array}{c}+138.60 \\
(3504 \mathrm{EGP}\end{array}$ \\
\hline
\end{tabular}

Ahmad, (2002) in a study to estimate the economics of rearing of Buffalo, Sahiwal and Crossbred heifers in Pakistan, reported that the total cost per buffalo was Rs. 11158 (968.36 EGP) while, the total revenue was Rs. 14860 (1289.64 EGP) and the profit per animal was Rs. 3702 (321.28 EGP) and output input ratio was (1.33:1). He recommended that: 1 . The buffalo heifers needs pond for wallowing in summer which is necessary it will decrease labor utilized for sprinkling water on the animals and 2. Rearing of heifers on concentrate ration for milk production is a profitable business.

Khan et al., (2008) in a study to estimate the effect of pregnancy on lactation milk value in dairy buffaloes, found a decrease in the milk yield with the increasing service period. However, Lactation milk value by (Rs) showed a declining trend. It suggested that an animal conceiving at an earlier stage of lactation returns better in monetary terms than those conceiving later, which contradicts the prevailing opinion among the conventional farmers, who desire to delay breeding for the loss of milk with the onset of pregnancy. They added, although in shorter term there is an immediate saving in milk but prolonged lactation and calving interval the financial returns are reduced in late conceivers. Calving interval increased with delayed conception, showing a consistent trend, in the low, moderate and high yielding buffaloes. There was a consistent decline in milk yield per day of calving interval with delayed conception, associated with prolonged calving interval. An animal conceiving at a later stage of lactation showed a decline in financial returns by 24 to $27 \%$ than those conceiving early.

Ebrahim, (2012) in a study of Friesian cows under semi intensive farming system in Egypt, reported that extension of medium milk 
producer cows with ideality period for calving interval, days open and dry period but shorter lactation period are more profitably than those have shorter and longer calving interval and days open. Additionally, ElAwady, (2013) on Friesian cows, conclude that under the intensive production system in Egypt, high milk producer cows with long calving interval are more profitably than those having regular calving every $12-$ 13 months.

\section{CONCLUSION}

The present results indicated that high milk producers buffaloes (L3) with longer lactation period but shorter dry period, days open and calving interval are more profitable than those have shorter lactation period, longer dry period, longer days open and longer calving interval. The present results suggests, under the Egyptian conditions, the buffalo which produces less than $6 \mathrm{~kg}$ milk per day must be called from breeding either large farms or small holder because they costed more than return it particular in the resent years under increasing prices of feed animals.

\section{REFERENCES}

Abo Gamoes, R. H. (2012). Genetic evaluation of production traits in Egyptian buffaloes. Ph. D. Thesis, Fac. Agric., Mansoura Univ., Egypt.

Abu El-Naser, I. A. (2008). Genetic and non-genetic factors affecting somatic cell counts and their relationship to milk traits and milk constituent in Egyptian buffaloes. M. Sc. Thesis, Fac. Agric., Kafrelsheikh Univ., Egypt.

Ahmad, M. (2002). Economics of rearing of Buffalo, Sahiwal and Crossbred heifers up to maturity. Int. J. Agri. Biol., 4: 153-155.

Ahmad, M.; K. Javed; W. Shahzad; F. Mehmood and M. H. Khan (2013). Some environmental factors affecting performance traits in registered Nili Ravi buffalo population at field area of Pakistan. Buffalo Bulletin, 32: 764-767.

Awad, S. S. and H. Z. Hassan (2006). Effect of environmental and management of productive performance and reproductive in buffaloes. J. Agric. Sci. Mansoura Univ., 31: 6987-6997.

Aziz, M. A.; S. J. Schoeman; G. F. Jordaan; O. M. El-Chafie and A. T. Mahdy (2001). Genetic and phenotypic variation of some reproductive traits in Egyptian buffalo. South Afric. J. Anim. Sci., 31:195-199.

Barnard, C. S. and J. S. Mix (1993). Farm planning and control: Budgeting and programming planning, $2^{\text {nd }} \mathrm{Ed}$, Cambridge University Press, Cambridge, UK.

Barros, C. C.; D.P. Oliveira; N.A. Hurtado-Lugo; R.R. Aspilcueta-Borquits and $\mathrm{H}$. Tonhati (2014). Estimates of genetic parameters for economic traits in dairy buffalo. In 10th World Congress on Genetics Applied to Livestock Production. Canada, Vancouver 19-24 August, 2014.

Barros, C. C.; R. R. Aspilcueta-Borquits; H. Tonhati and A. B. Fraga (2013). Genetic parameters for productive and reproductive traits for milk buffalo in Brazil. Buffalo Bulletin, 32: 688-691. 
Ebrahim, S. Z. M. (2012). Productive and reproductive characteristics of Friesian cows under semi intensive farming system in Egypt. Ph. D. Thesis, Fac. Agric., Kafrelsheikh Univ., Egypt.

El-Awady, H. G. (2009). Genetic and economic evaluation for milk yield traits of lactating Egyptian buffalo including lactose and somatic cell counts. J. Agric. Res. Kaferelsheikh Univ., 35: 823-840.

El-Awady, H. G. (2013). Effect of milk yield on economic profitability of Holstein Friesian cows under intensive production system in Egypt. Pak. Vet. J., 33: 23-26.

El-Azab, M. A. A. (2006). Comparing a group of selection indexes for genetic improvement of some milk production traits in the Egyptian buffaloes. M. Sc. Thesis, Fac. Agric., El-Azhar Univ., Egypt.

Harvey, W. R. (1990). Users guide for LSMLMW, Mixed model least squares and Maximum Likehood computer program. PC-2 Version. Ohio State, University, Columus (Mimeograph), USA.

Hintz, R. L.; R. W. Everett and L. D. Vleck (1978). Estimation of genetic trends from cow and sire evaluations. J. Dairy Sci., 61: 607-613.

Hussain, Z.; K. Javed; S. M. I. Hussain and G. S. Kiyani (2006). Some environmental effects on productive performance of Nili-Ravi buffaloes in Azad Kashmir. J. Anim. PI. Sci., 16: 66-69.

Khalil, M. H.; E. A. Afifi; L. H. Bedeir and S. M. Zeidan (1992). Genetic analysis of lactation traits in Egyptian buffaloes. Egypt. J. Anim. Prod., 29: 155-172.

Khan, M. S.; F. U. Hassan; S. U. Rehaman; A. U. Hyder and I. R. Bajwa (2007). Genetic control of milk yield from lactation of different duration in Nili-Ravi buffaloes. Archiv-fur-Tierzucht, 50: 227-239.

Khan, S.; M. S. Qureshi; N. Ahmad; M. Amjed; F. R. Durrani and M. Younas (2008). Effect of pregnancy on lactation milk value in dairy buffaloes. Asian-Aust. J. Anim. Sci., 21: 523-531.

Khattab, A. S. and K. A. Mourad (2007). In breeding and its effects on some productive traits in a herd of Egyptian buffaloes. ITAL. Anim. Sci., 6: 275-278.

Mahdy, A. E.; O. M. El-Shafie and H. A. Rigalaty (2001). Relative importance of some factors affecting performance traits in a herd of Egyptian buffaloes. Alex. J. Agric. Res., 46: 1-18.

MARL (2015). Ministry of Agriculture and land reclamation, Livestock development sector, 2015.

Mentiel, C. C. Ch. M.; N. Montiel-Urdaneta; R. Rincón; N. Berrios; N. S. Morillo; J. Belandria; M. Andará and J. Arias (2013). Productive and reproductive parameters in buffaloes and cows in a farm located in tropical dry forest in Venezuela. Buffalo Bulletin, 32: 812.

Mourad, K. A. and A. S. Khattab (2009). A comparison between different selection indices for some productive traits on Egyptian buffaloes. Arch. Tierz., Dummerstorf, 52: 476-484.

Mourad, K. A.; T. A. Fooda; K. A. Shahin and A. A. Ashmawy (2005). Lactation curve milk production and days open in Egyptian buffaloes. J. buffalo Sci. and Technique Bubalus, 11:3. 
Mourad, K. A.; E. A. Afifi and L. H. Bedier (1990). Non-genetic factors influencing milk production traits in Egyptian buffaloes. Egypt. J. Anim. Prod., 27: 1-18.

Qureshi, M. S.; G. Habib; H. A. Samad; M. M. Siddiqui; N. Ahmad and M. Syed (2002). Reproduction-nutrition relationship in dairy buffaloes. I. Effect of intake of protein, energy and blood metabolites levels. AsianAust. J. Anim. Sci., 15: 330-339.

Sanker, S.; D. Kumar; K. G. Mandal; R. K. Taggar and A. K. Das (2014). Factors influencing the dry period and calving interval in different grades of buffaloes. Buffalo Bulletin, 33: 120-126.

Thiruvenkadan, A. K.; S. Panneerselvam; R. Rajendran and N. Murali (2010). Analysis on the productive and reproductive traits of Murrah buffalo cows maintained in the coastal region of India. Applied Animal Husbandry \& Rural Development, 3: 1-4.

Zafar, A. H.; M. Ahmed and S. U. Rehman (2008). Study of some performance traits in Sahiwal cows during different periods. Pakistan Vet. J., 28: 84-88.

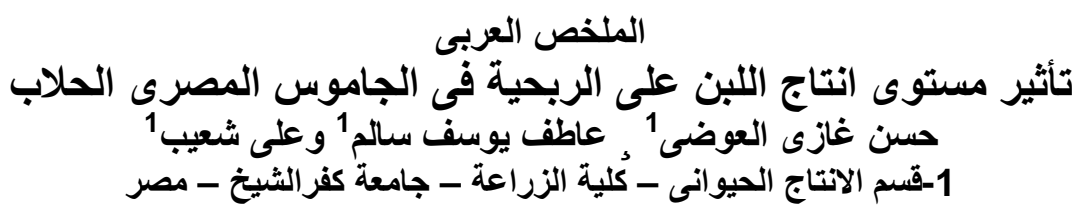

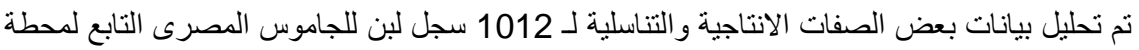

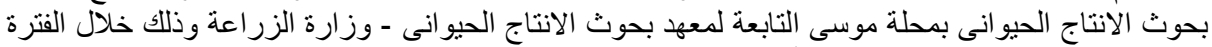

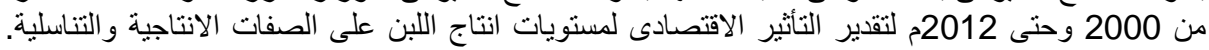

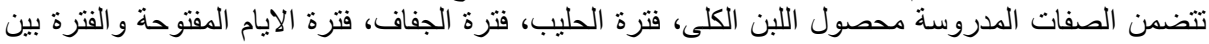

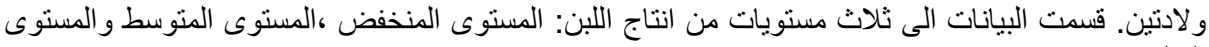

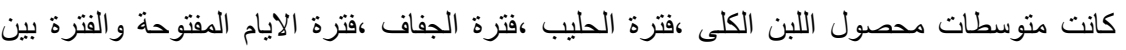

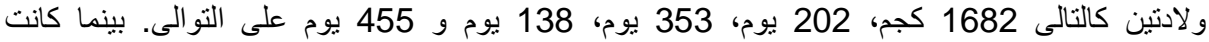

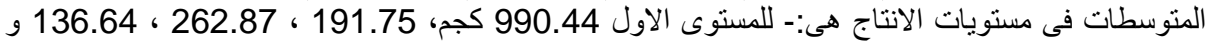

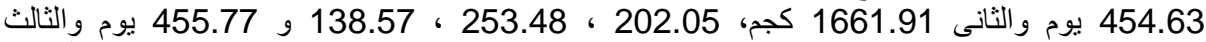

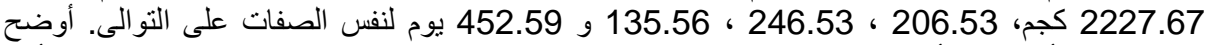

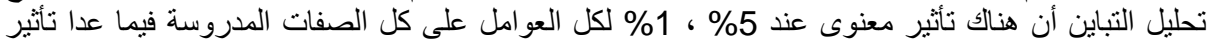

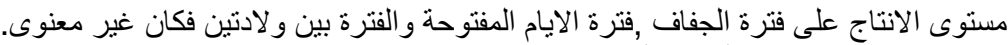

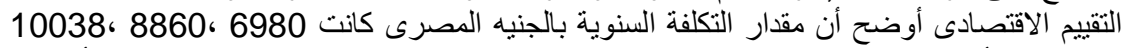

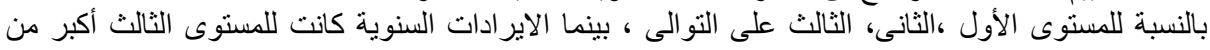

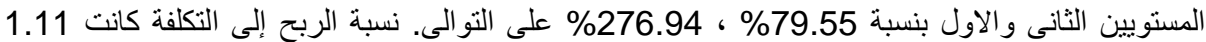

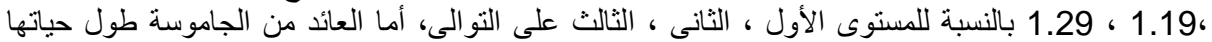

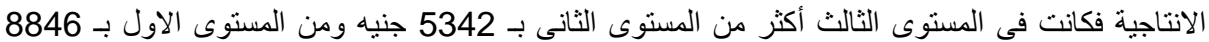

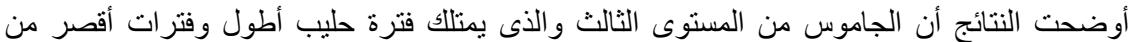

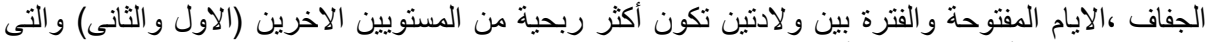

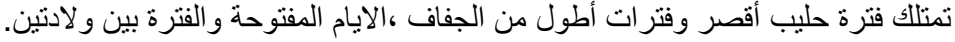

